\title{
Pregnancy by Bovine Blastocysts Developed in Co-Culture with Cumulus/Uterine Endometrial Cells after in Vitro Fertilization
}

\author{
Yutaka Kajihara, Naoko Kometani, Satomi Kobayashi, Yuji Shitanaka ${ }^{2)}$, and Kazufumi Goto ${ }^{1)}$ \\ Technical Research Center, Marubeni Shiryo Co., Ltd., Otaru 1292, Shinbe-cho, Ono, Hyogo 675-13 \\ ${ }^{1}$ Department of Animal Science, Faculty of Agriculture, Kagoshima University, Kagoshima 890 \\ ${ }^{2)}$ ITOHAM FOODS INC., Takahata 4-27, Nishinomiya, Hyogo 663
}

(Accepted for publication February, 1991)

\begin{abstract}
Summary. This study determines the optimum time of transfer for bovine blastocysts derived from in vitro matured follicular oocytes fertilized in vitro. A slightly modified method of bovine in vitro fertilization previously described was used. Frozen-thawed spermatozoa were washed 3 times with modified Brackett and Oliphant medium after thawing, then pre-incubated for 2 to $3 \mathrm{hr}$ before incubation with matured oocytes. Seventy-eight to $83 \mathrm{hr}$ after fertilization, the cumulus cells removed from the oocytes were cultured at the bottom of the culture dish along with those already released. The oocytes were cultured in dishes with cumulus cells (CCL) or with combinations of cumulus cells and monolayer of uterine endometrial cells (CUL) to examine further development. The embryos that developed into blastocysts were transferred to recipients on days 7 to 9 post-fertilization (day of insemination $=$ day 0$)$. One to 3 blastocysts were non-surgically transferred to recipients on days 5.5 to 8.5 of the estrous cycle (estrus=day 0 ). Ultrasonography was used to diagnose pregnancy around 50 days post-transfer. Developmental rate of embryos to the blastocyst stage was higher $(\mathrm{P}<0.01)$ in CUL than in CCL culture system $(39.4 \%$ vs $25.9 \%)$. The relative synchrony between day of the estrous cycle of recipients and the age of embryos effected on pregnancy rates. Pregnancy rates were higher $(\mathrm{P}<0.01)$ in 2 days than in 3 days asynchronous transfer between estrous cycle stages of recipient and embryo ages. To date 29 single births, 10 sets of twins and 2 sets of triplets have resulted from these experiments.
\end{abstract}

KEY WORdS: IN VITRO FERTILIZATION, FOLLICULAR OOCYTES, CO-CULTURE, BLASTOCyST, EMBRyo TRANSFER.

Jpn J Anim Reprod 37, 177-184, 1991

\section{卵丘細胞・子宮内膜上皮細胞との共培養により得られた 体外受精由来胚盤胞期胚の移植成績}

\author{
梶原豊・米谷 尚子・小林 里美 \\ 下中 裕次 $^{2)} \cdot$ 後藤 和文 ${ }^{1)}$ \\ 丸紅飼料株式会社 技術センター テ $675-13$ 兵庫祡小野市新部町小垂 1292

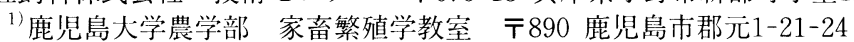 \\ 2) 伊藤八厶株式会社 国内原料部 $\overline{\mathbf{T}} 663$ 兵庫県西宮市高畑町 4 番 27 号
}


くはホルスタイン種に移植して生ませ，その子牛を肥育 素牛として利用する低コスト和牛生産体制の確立, 普及 が望まれている。

牛の体外受精における精子の受精能獲得法は雌生殖器 を用いた Iritani と Niwa（1977），牛卵胞液を用いた Von Bregulla ら (1974), 高張のイオン濃度液を用いた Brackett ら (1982), カルシウムイオノフオア液を用い たByrdら（1981）の先駆的研究により進展し, Brackettら（1982）が体外受精胚の移植による最初の産子を 得た。 その後 Lambert ら (1986), Sirard と Lambert （1986）は内視鏡を用いて卵巣から成熟卵子を取り出し, 体外受精する方法で子牛の作出に成功した。一方, Hanada ら (1986), Crister ら（1986）（1986年 2 月に産 子を得たと共同実験者の Leibfried-Rutledge が1989年に 報告している）は体外成熟卵の体外受精による子牛の作 出に成功し, 今日の実用的技術への基盤を成した.

近年, Minato ら（1989）は牛卵胞卵子を体外受精後 に偽妊娠ウサギの卵管を用いて培養し, 発育した肧の移 植により多数例の受胎，分娩例を報告した。 そのなかで, 体外受精一ウサギ卵管内発育肧では, 移植胚の日歯命と受 顼牛の性周期日齢との差の許容範囲が大きいことを示し ている.

ウサギ卵管を用いる培養法は, 一連の操作が複雑なこ と, 初期胚の発生機構の解明が困難であることなどから 完全体外発育培養系の開発・実用化が望まれてきた。

その後, 卵丘細胞を用いた完全体外培養系により作出 された牛胚盤細胞期胚の移植によりあいついで産子が得 られた (Goto et al., 1988, 1989; Lu et al, 1988; Eyestone and First 1989; Fukuda et al., 1990; Kajihara et al., 1990).このことにより，体外培養由来胚の正常性の一 端が部明され，その実用化が試みられつつある。

本研究では, 体外成熟一体外受精後, 卵丘細胞と子宮 内膜上皮細胞を用いた完全体外培養系により作出した牛 肧盤胞期胚について，移植所要時間，移植に用いた胚日 齢，移植に用いた受胚牛の性周期日齢等が受胎性におよ ぼす影響について調べた。

\section{材料と方法}

卵子：供試卵巣は加古川市食肉センターで採材した。卵 梁衣缃に存在する直径 1 ～ $7 \mathrm{~mm}$ の小卵胞から, 20G の注射針を付けた注射筒で卵胞液とともに卵胞卵子を吸 小採取した。卵胞卵子は，ピペットで時計血間を移動す ることにより，夾雑物と卵胞液を除去した。卵丘細胞が 卵子の周囲に $1 / 3$ 以上付着しており細胞質が形態的に均
一で良好な卵子のみを選抜し, 洗浄後, 成熟培養に供し た。成熟用培養液および発生用培養液は前報（Kajihara et al., 1987）に準じた.なお，成熟培養時間は20～22時 間とした.

精子：人工授精用の和牛凍結精液ストローを温水（32～ $\left.35^{\circ} \mathrm{C}\right)$ 中で解凍し，テオフィリン (Sigma, T-1633) 5 $\mathrm{mM}$, 牛血清アルブミン (Sigma, A-4378) $2.5 \mathrm{mg} / \mathrm{ml}$, ヘパリン (Sigma, H-9133) $10 \mu \mathrm{g} / \mathrm{ml}$ (Parrish et al., 1986; Niwa and Ohgoda, 1988) を添加した m-B.O. 液 (原法 Brackett and Oliphant, 1975) を加え，700 g, 5 分間の遠心操作を 3 回繰り返して洗浄した。精子濃度は $15 \times 10^{6} / \mathrm{ml}$ に調整し, 直径 $35 \mathrm{~mm}$ のシャーレに $100 \mu \mathrm{l}$ の小滴とし，上面は流動パラフィンで覆って $2 \sim 3$ 時間 の前培養を行った。

体外受精及びその後の胚の発生方法：体外成熟の終わっ た卵子を m-B.O. 液にて洗浄し, 上記の前㠺養の終了し た精子小滴内に移して体外受精を行った。

授精開始から20２1時間後にサンプリングを行い，標 本を作製した，カルノア液で固定し，オルセイン染色を 施した。第一・第二極体, 膨化した一対の雄此両前核の 存在をもって正常受精胚とした（Table 1).

体外受精開始 6〜 7 時間後に子牛血清 $1 \%$ と抗生物質 を含む25 mM HEPES 緩衝 TCM-199中に卵子を移した。 前報（Kajihara et al., 1987）に準じた培養系（CCL区）， 及び授精後 $0 ， 2 ， 3$ 日目に子宮内膜、波細胞に添加し た培養系（以下 CU0，CU2，CU3区）により発生培養 を行った，授精後78〜83時間に卵厅絒胞略または卵「細 胞と子宮内膜上皮練胞の混在する層より肧抢よび卵子を 遊離させ，同時に培養液を交換し，さらに2 日後にも培 養液の交換を行った。授精後 2 日目及び 3 日目に 8 細胞 期以降に発育した肧の数，5 日目に桑冬肧期以降に発育 した胚の数，7〜10日目に胚盤胞期に発言した胚の数を 調べた (Table. 2).

新鮮体外受精胚の移植方法：上記の培養系により授精後 $7 \sim 9$ 日目に得られた新鮮肧盤胞期胚を移植または凍結 に用いた。

限定した 5 人の観察者により Standing 発情（以下 S.E.) または発情と報告された延べ134䫑の未経産牛（ホ ルスタイン種, 交雑種) と1頭の経産牛: (交雑種), 計 135頭を受胚牛とした。この135頭のうち延べ 6 回の移植 によっても受胎しなかった 2 頭, 黄体形成不全, 中〜大 卵胞共存，重症の下痢等の理由により移植しなかった延 べ13頭についてはデータの解析から除いた。 また，延べ 7 頭については移植器の頸管通過が不能であり, 移植を 
Table 1. In vitro maturation and fertilization rates of bovine follicular oocytes

\begin{tabular}{ccccc}
\hline $\begin{array}{l}\text { Semen } \\
\text { donor }\end{array}$ & $\begin{array}{l}\text { No. of } \\
\text { oocytes } \\
\text { examined }\end{array}$ & $\begin{array}{l}\text { No. (\%) } \\
\text { of oocytes } \\
\text { matured }\end{array}$ & $\begin{array}{l}\text { No. (\%) } \\
\text { of oocytes } \\
\text { fertilized* }\end{array}$ & $\begin{array}{r}\text { No. (\%) of } \\
\text { polyspermy }\end{array}$ \\
\hline I & 46 & $44(95.7)$ & $27(58.7)$ & $11(23.9)^{\mathrm{b}}$ \\
$\mathrm{K}$ & 70 & $65(92.9)$ & $46(65.7)$ & $5(7.1)^{\mathrm{t}}$ \\
Combined & 116 & $109(94.0)$ & $73(62.9)$ & $16(13.8)$ \\
\hline
\end{tabular}

* Follicular oocytes were matured for 20-22 hrand then examined after additional culture with spermatozoa for $20-21 \mathrm{hr}$.

a.b) Means with different superscripts in the same column are significantly different $\left(\mathrm{P}<0.05, \chi^{2}\right.$-test $)$.

Table 2. The effects of cell types used for co-culture on in vitro development of bovine embryos

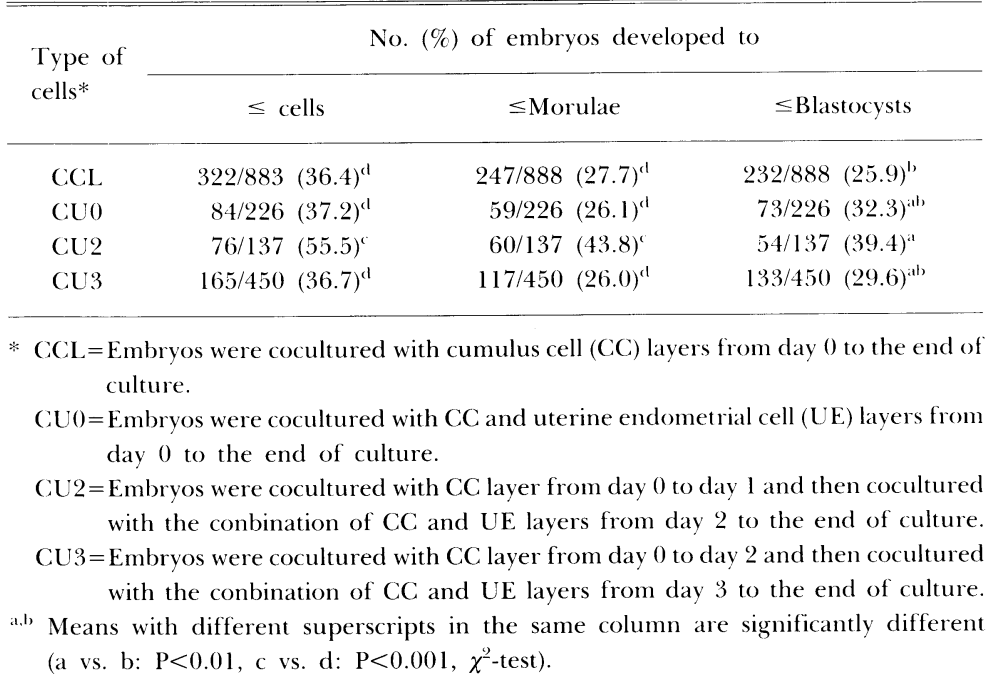

断念した.

$0.25 \mathrm{ml}$ 容量のカスー製ストローを用い, 1 ～ 3 個の 胚を Suzukiら（1989）およびYamashina（1990）の報 告を参照してなるべく両側子宮角に非外科的移植を施し た。移植用液として m-PBS と TCM-199を等量混合し たものに子牛血清を $20 \%$ 添加して用いた。移植は 3 名に 限定して行った.

受胎の確認方法：胎児日歯令約55日 (移植日より約48日目) に2 名以上による直腸検査と超音波診断により受胎の有 無，胎児数を推定した。

検討項目と検討方法：1：移植器を牛体に挿入した時点 から移植完了までの時間が14分以内の場合と, 15分〜 50 分かかった場合にわけて受胎率を比較した（Tablb 3).
2 : 授精日を0日目として7.0から9.0日目に得られた胚 盤胞期胚を S.E.より $6.0 〜 7.5$ 日歯の受胚牛に移植し, 移植に用いた胚日齢が受胎率に及ぼす影響を検討した (Table 4).

3 : S.E. を確認，もしくは S.E. と推定した日を day0と して，5.5から8.5日齢にある受胚牛に7.0から8.5日齢の 胚盤胞期胚を移植し，受胚牛の日齢が受胎率に及ぼす影 響を検討した（Table 5).

4 ：移植に用いた胚日齢と受肧牛の性周期日歯令間の差が 受胎率におよぼす影響を検討した。日齢差－2.0日は， 授精後8.0日の肧を S.E. 確認から6.0日目の受肧牛に移 植したことを示す (Table 6).

統計処理： $\chi^{2}$ 検定により各実験区間の有意差を検定し 
Table 3. The effect of the time required for embryo transfer on pregnancy rates

\begin{tabular}{cccc}
\hline $\begin{array}{l}\text { Time }(\min ) \\
\text { Mean } \pm \text { S.D. }\end{array}$ & $\begin{array}{l}\text { No. of } \\
\text { recipients }\end{array}$ & $\begin{array}{l}\text { No. } \\
\text { pregnant }\end{array}$ & $\begin{array}{l}\text { Pregnancy } \\
\text { rate }(\%)\end{array}$ \\
\hline $\begin{array}{l}2 \text { to } 14 \\
6.8 \pm 3.0\end{array}$ & 72 & 41 & 56.9 \\
15 to 50 & 31 & 17 & 54.8 \\
$21.8 \pm 8.3$ & & & \\
\hline
\end{tabular}

Means were not significantly different with $\chi^{2}$-test $(\mathrm{P}>0.05)$.

Table 4. The effect of the day IVF embryos reached the blastocyst stage on pregnancy rate

\begin{tabular}{cccc}
\hline $\begin{array}{l}\text { Days of } \\
\text { (mbryo* }\end{array}$ & $\begin{array}{l}\text { No of } \\
\text { recipients }\end{array}$ & $\begin{array}{l}\text { No. } \\
\text { pregnant }\end{array}$ & $\begin{array}{l}\text { Pregnancy } \\
\text { rate }(\%)\end{array}$ \\
\hline 7.0 & 14 & 7 & $50.0^{\mathrm{b}}$ \\
7.5 & 17 & 15 & $88.2^{\mathrm{a}}$ \\
8.0 & 26 & 17 & $65.4^{\text {at }}$ \\
8.5 & 19 & 13 & $68.4^{\text {at) }}$ \\
9.0 & 7 & 2 & $28.6^{\text {bc }}$ \\
\hline
\end{tabular}

* Day $0=$ day of in vitro insemination

:-1 Means with different superscripts in the same column are significantly different (a vs. b: $\mathrm{P}<0.05$, a vs. c: $\mathrm{P}<0.01$, $\chi^{2}$-test).

た.

\section{結 果}

体外受精率：本研究では 6 頭の種雄牛に由来する凍結精 液を用いたが，主として用いた 2 頭の精液による授精後 20２1琮間に扮ける卵胞卵子の体外成熟率および体外受 精率を Table 1 に示した。

授精20～21時間後に検査したすべての供試卵子につい ての正常受精率は, 種雄牛 I で58.7\% (27/46), 種雄牛 Kでは $65.7 \%$ (46/65) であり，有意な差はみられなか ったが，種雄牛 I では，多精子侵入率が $23.9 \%(11 / 46)$ と種雄牛Kの7.1\%（5/70）に比べて有意（P<0.05） に槀かった。また，I，K両種雄牛をまとめた受精率は 62.9\% (73/116) であった.

な抢 6 頭の種雄牛に由来する体外受精胚の非外科的移 植によりいずれの個体でも受胎例を得ることができた.

胚の発生成績に及ぼす共培養に用いた細胞の影響 : 従来 から用いてきた培養系 (CCL 区) と，授精後 $0 ， 2$ ， 3 日目に子宮内膜上皮細胞を添加した培養系（CU0，
Table 5. The effect of the day of the recipient estrous cycle on pregnancy rate

\begin{tabular}{lccl}
\hline $\begin{array}{l}\text { Day of } \\
\text { estrous cycle* }\end{array}$ & $\begin{array}{l}\text { No. of } \\
\text { recipients }\end{array}$ & $\begin{array}{l}\text { No. } \\
\text { pregnant }\end{array}$ & $\begin{array}{l}\text { Pregnancy. } \\
\text { rate }(\%)\end{array}$ \\
\hline 5.5 & 12 & 4 & $33.3^{\text {b }}$ \\
6.0 & 30 & 22 & $73.3^{\text {a }}$ \\
6.5 & 33 & 22 & $66.7^{\text {ac }}$ \\
$7.0-7.5$ & 16 & 8 & $50.0^{\text {atb }}$ \\
$8.0-8.5$ & 7 & 2 & $28.6^{\text {bx }}$ \\
\hline
\end{tabular}

*Day $0=$ day of standing estrus

The embryos of blastocyst stage were used for transfer.

atc Means with different superscripts in the same column are significantly different (a vs b or c: $\mathrm{P}<0.05, \chi^{2}$-test).

Table 6. The effect of recipient day of synchrony and age of embryos on pregnancy rate

\begin{tabular}{cccc}
\hline $\begin{array}{l}\text { Days from } \\
\text { synchrony }\end{array}$ & $\begin{array}{l}\text { No. of } \\
\text { recipients }\end{array}$ & $\begin{array}{l}\text { No. } \\
\text { pregnant }\end{array}$ & $\begin{array}{l}\text { Pregnancy } \\
\text { rate }(\%)\end{array}$ \\
\hline-3.0 & 10 & 3 & $30.0^{\mathrm{b}}$ \\
-2.5 & 8 & 5 & $62.5^{\text {ab }}$ \\
$-2.0^{*}$ & 22 & 18 & $81.8^{\mathrm{at}}$ \\
-1.5 & 17 & 10 & $58.8^{\text {ab }}$ \\
-1.0 & 27 & 16 & $59.3^{\text {ab }}$ \\
0 to +1.0 & 13 & 6 & $46.2^{\text {ab }}$ \\
\hline
\end{tabular}

*The recipients were 2 days behind the embryos.

a. b Means with different superscripts in the same column are significantly different $\left(\mathrm{P}<0.01, \chi^{2}\right.$-test $)$.

CU2，CU3区）による発生成績を Table 2 に示した。

8 細胞期以上への発考率はCU2区が他の 3 区に比べ て有意 $(\mathrm{P}<0.001)$ に高かった。

桑実胚期以上への発育率も同様にCU2区が他の 3 区 に比べて有意 $(\mathrm{P}<0.001)$ に高かった. 肧盤胞期以上 への発育率は CU2区が他の 3 区に比べて高く, とくに CCL 区に対しては有意 $(\mathrm{P}<0.01)$ に高かった。

移植所要時間と受胎率：移植に要した時間が受胎率に及 ぼす影響を Table 3 に示した. 14分以内（平均6.8土3.0 分）に移植できた場合の受胎率は，56.9\% (41/72) で あり，15分５0分 (平均 $21.8 \pm 8.3$ 分) かかった場合の 受胎率54.8\%（17/31）とほぼ同様の值であった，黄体 は左右別に41頭と62頭となり右にある場合が多かった。

胚日齢と受胎率：移植に用いた胚日齢が受胎率におよほ す影響については Table 4 に示した。授精後7.0，7.5， $8.0 ， 8.5$ ，および 9.0 日目に得られた肧盤胞期肧を移植 した場合の受胎率はそれぞれ50\% (7/14), 88.2\% (15/17)， 
65.4\% (17/26)，68.4\% (13/19)，抽よび28.6\% (2/7) であった。受胎率は7.5日目に得られた胚が, 7.0 日目（P $<0.05 ）$ あいは 9.0 日目 $(\mathrm{P}<0.01)$ に得られた肧よ りも有意に高かった８.0日目拉よび8.5日目に得られた 胚の受胎率は，他の区と比べ有意差はなかった。

受胚牛の性周期日齙と受胎率：移植に用いた受胚牛の性 周期日鈛が受胎率におよぼす影響については Table 5 に 示した. S.E.より $5.5,6.0,6.5,7.0$ 7.5および8.0〜 8.5 日目の受胚牛に7.0 8.5日齢の胚盤胞期胚を移植し た場合の受胎淬はそれぞれ, 33\%(4/12), 73.3\% (22/30)， $66.7 \%(22 / 33) ， 50 \%(8 / 16)$ ，および29\% (2/7) であ った。受胚牛の日龄が 6.0 日目であった場合の文胎率は, 5.5および8.0ー8.5日目であった場合よりも有意に（P <0.05）高く，6.5日目であった場合の受胎率は，5.5日 目の場合よりも有意 $(\mathrm{P}<0.05)$ に高かった。また7.0〜 7.5日目であった場合の受胎率は，他の区に比べ有意差 はなかった。

\section{移植胚日齢と受胚牛の性周期日齢との日齢差と受胎率：}

移植胚の日歯と受胚牛の性周期日歯差が受胎率に及ぼす 影響についてはTable 6 に示した. 日齢差がー3.0, - 2.5, $-2.0,-1.5,-1.0$ および $0 〜+1.0$ であった場合の受 胎率はそれぞれ30\% (3/10)，63\% (5/8), 81.8\% (18/22)， $58.8 \%$ (10/17)，59.3\% (16/27）および46\% (6/13) であった。受胎率は日齢差がー2.0日ずれている場合が -3.0日ずれている場合に比べ有意 $(\mathrm{P}<0.01)$ に高か った. $-2.5,-1.5,-1.0$ および $0 〜+1.0$ 日ずれてい る場合は，他の区に比べ有意差はなかった。

分婏成績：妊娠確認後に妊娠牛の死亡（1例)，および 出荷（1 例）があり, 56頭の妊娠牛より41の出産例を得 た。流産率は $26.8 \%(15 / 56)$ であった。子牛の内訳は 29頭の単子, 10 組の双子, 2 組の三子となり雌雄別にそ れぞれ21頭，34頭であった。

\section{考察}

CU0掞よびCU3区では，授精 7 〜 10日目の観察で胚 盤胞期胚への発育率が桑実経胚への発育率を上回ってい たがこれは桑実期胚への発生に対して CU0および CU 3 区は発生培養系として不完全（時間的に）である 可能性を示している. Sugie（1973）は排卵後屠殺まで の日数別に採卵部位（卵管と子宮）を調べた結果，子宮 からの胚の採取率は 2 日目で $28.9 \% \quad(24 / 83), 3$ 日目で $53.1 \%(111 / 209) ， 4$ 日目では $74.6 \%$ (170/232) であ ったと報告しており，授精後 3 日目に半数以上の肧が子 宮角先端部に移行していることが示されている．本実験
で肧の体外培養系に子宮内膜上皮細胞を添加した例では， 子宫内膜上皮細胞は培養血底面に約 24 時間かかって接着 し，その後増殖，代謝が開始され，子宮内と同じ様な環 境が作り出されていくものと考えられる。 これが CU 2 区において胚の 8 細胞期への発育と 8 細胞期を越えての 発育に好影響をもたらしたものと考えられる。実際に本 培養系に由来する胚の移植に関する予備試験で既に受胎 例が得られている (Kajihara et al., 1989).

本実験で移植に要した時間の長さは受胎率に影響を及 ぼさかった。このことは，頸管への長時間（50分以内） の刺激は受胎率にさほど影響しないこと，本実験で用い た m-PBSと TCM-199の等量混合液に子牛血清を $20 \%$ 添加した液は移植用として適切であったことなどを示唆 している.

これまでに体外成熟一授精一培養により得られた肧盤 胞期胚 (以下 IVMFC 胚), さらにそれらの分割や凍結 一融解後の胚の移植による多数の受胎分婏例が報告され ている.しかし一方でIVMFC 胚の移植により過大産 子の発生 (Miura et al., 1989; Minato et al., 1989), 妊 娠期間の延長（Minato et al., 1989）などが報告されて おり，これらが体外培養系の不備に起因していることも 考えられる。これまでに 1) IVMFC 肧は，過排卵処 理に由来する肧に比べて，コルセミド耐性が低く染色体 数異常率の高い（Tokumaru et al., 1989）こと, 2) IVMFC 胚の $19.3 \%$ で，内細胞魂の細胞数が計測できな かったか, 認められなかった（Iwasaki et al., 1990）こ と，3）IVMFC 胚の割球数には大きな変異がみられた (Kajihara et al, 1988) こと, さらに4) 牛 IVMFC 胚 は生体回収胚に比べて透明体の弾力性が弱く, 割球間の 結合がゆるい（Goto, 私信）こと等が報告されている. これらの報告は現在の牛体外成熟一体外受精一体外培養 系はいまだ胚の正常発生にとって完全なものではないこ とを示唆している.

本研究において, 体外受精後7.5〜8.5日目に得られた 胚を移植した例では，受胎率は9.0日目に得られた胚よ りも高く, Goto ら (1988a, b) の報告と同様な結果で あった。また, Kometaniら (1989) が体外受精後, 7, 8 および 9 日目に凍結した IVMFC 胚を融解後に培養 して得た生存率（7日目：76.2\%，8日目：68.8\%，9 日目：43\%）をみても，9 日目の胚よりも前 2 者がすぐ れていた．以上の結果より 9 日目に得られたIVMFC 胚は 7 ～ 8 日目に得られた IVMFC 胚に比べて異なる 環境への順応性が低く, 移植後の発生率も劣っていると 思われる．また，Kajiharaら（1988）は肧盤胞期で17\% 
（7/41）であった染色体異常率が脱出途中～脱出肧盤胞 期では35\%（6/17）に上昇したことを報告しており，長 期間の培養，もしくは胚盤胞期への発育に長時間を要し た胚では染色体，染色体数等に異常をきたした可能性が 高い.このことから受精後 $7 ， 8$ 日目に胚盤胞期胚にま で発育するような培養系を今後開発する必要があると考 えられる.

生体からの過排卵一回収胚を用いたHasler et al., （1987）によれば，供胚牛と受胚牛の発情周期日数の差 がさ1.5日であれば，受胎率は良好であったと報告して いる. 本研究の IVMFC 胚を用いた例では，-2.5日か ら+1.0日間のずれの範囲でも受胎率は良好であり, 特 にー2.0日ずれている場合にすぐれた結果が得られた。 このことは，胚盤腔形成を経て同様に胚盤胞期の形態を していてもIVMFC 胚は，生体からの回収胚に比べて 测球数が少なく発育が遅れているので, 若いステージの チ沁に移植した方が肧の生存率並びに受胎率が高くなる ことを示唆している。また体外受精胚は生体由来胚と異 なり，体内のホルモン支配下におかれていなかったので， 比較的移植後の新しい子宮環境に順応する能力, つまり 月齢の許容範囲が大きい可能性がある.さらら筆者ら (未 発表）はガス分圧等の胚の培養条件が変わると移植に最 適の胚と受肧牛の日齢差が変わってくることを経験して いる.

流産率は $26.8 \%$ と高かったが，これは受胚牛の多くが 一産取肥育のために妊娠確認後も肥育を続けたのが主因 と思われ，また複数の胚を移植した (Izaike et al., 1988) こと, さらに完全体外培養系で肧盤胞期にまで発育させ た脽を使ったことなど複合的な要因が重なったことに起 因していると考えられる。

出産された子牛の性別は雌21頭, 雄34頭でやや雄の比 率の高い傾向がうかがえた。この種の研究初期には雄産 子が生まれる割合が高いことが知られている (Goto et al., 1989; Miura et al., 1989). 前報 (Kajihara et al., 1988) で, 本研究とほぼ同様の培養系に由来する肧について染 色体数の異常を検討した結果，雌胚で $37 \%$ ，雄胚で $14 \%$ の制合であった。このことと生産された子牛に占める雄 ケトl:の割合が高かったこととは何らかの関係があるかも 矨机ない。

\section{謝 辞}

本程を校閲された京都大学農学部入谷 明教授とルイ ジアナ州立大学の Dr. R.A. Godke, Dr. E.G. Blakewood に深花なる謝意を表する。なお本研究の遂行に際して，
協力いただいた菱山和洋氏，小柴雄二氏，本田直樹氏， 加古川市食肉センター, 兵庫県食肉衛生検査センター, 伊藤八厶株式会社, 岡山県小林牧場, 兵庫県藤原牧場, 兵庫県佐用幸友ファーム, 岡山県中央牧場, 兵庫県村田 牧場の関係各位, および家畜受精卵移植技術研究組合に 深く感謝する.

\section{文献}

Brackett BG, Oliphant G (1975) Capacitation of rabbit spermatozoa in vitro. Biol Reprod 12: 260-274.

Brackett BG, Bousquet D, Boice ML, Donawick WJ, Evans JF, Dressel MA (1982) Normal development following in vitro fertilization in the cow. Biol Reprod 27: 147-158.

Byrd W (1981) In vitro capacitation and the chemically induced acrosome reaction in bovine spermatozoa. $J$ Exp Zool 215: 35-46.

Critser ES, Leibfried-Rutledge ML, Eyestone WE, Northey DL, First NL (1986) Acuisition of developmental competence during maturation in vitro. Theriogenology 25: 150 (abstr).

Eyestone WH, First NL (1989) Co-culture of early cattle embryos to the blastocyst stag with oviductal tissue or in conditioned medium. J Reprod Fert 83: 753-758.

Fukuda Y, Ichikawa M, Naito K, Toyoda Y (1990) Birth of normal calves resulting from bovine oocytes matured, fertilized, and cultured with cumulus cells in vitro up to the blastocyst stage. Biol Reprod 42: 114-119.

Goto K, Kajihara Y, Kosaka S, Koba M, Nakanishi Y, Ogawa K (1988) Pregnancies after co-culture of cumulus cells with bovine embryos derived from in-vitro fertilization of in-vitro matured follicular oocytes. $J$ Reprod Fert 83: 753-758.

Goto K, Kahihara Y, Koba M, Nakanishi Y, Ogawa K (1988) Pregnancy in cattle after transfer of bisected blastocysts obtained from in-vitro fertilization of oocytes matured in-vitro. Asian-Aust J Anim Sci 1: 153-156.

Goto K, Kajihara Y, Kosaka S, Koba M, Nakanishi Y, Ogawa K Oku T, Fujiyama M, Yoshida Y (1989) Normalities of calves obtained from the transfers of blastocysts produced by totally in-vitro technique. AsianAust J Anim Sci 2: 591-593.

Hanada A, Suzuki T, Shioya Y (1986) Birth of calves from non-surgical transfer of blastocyst originated from in vitro fertilized oocytes matured in vitro. $18 \mathrm{Jpn} J$ Zootech Sci (in Japanese, abstr).

Hasler JF, McCauley AD, Lathrop WF, Foote RH (1987) Effect of donor-embryo-recipient interactions on pregnancy rate in a large-scale bovine embryo transfer program. Theriogenology 27: 139-168.

Iritani A, Niwa K (1977) Capacitation of bull spermatozoa and fertilization in vitro of cattle follicular oocytes matured in culture. J Reprod Fert 50: 119-121.

Iwasaki S, Yoshida Y, Watanabe S, Nakahara T (1990) 
Differential nuclear staining and cell count of trophoectoderm and inner cell mass of bovine blastocyst fertilized in-vitro by double fluorochrome dye technique. Jpn J Anim Reprod 60-65 (in Japanese).

Izaike Y, Suzuki O, Shimada K, Fujita K, Kosugiyama M (1988) Twin pregnancy diagnosis and early embryonic loss after bilateral egg transfer in beef cattle. $J p n$ J A nim Reprod 34: 236-242.

Kajihara Y, Goto K, Kosaka S, Nakanishi Y, Ogawa K (1987) In vitro fertilization of bovine follicular oocytes and their development up to hatched blastocysts in vitro. Jpn J Anim Reprod 33: 173-180 (in Japanese).

Kajihara Y, Goto K, Tokumaru M, Koba M, Nakanishi Y, Ogawa K (1988) Number of blastomeres and chromosome abnormalities ofbovine blastocysts obtained from in vitro matured, fertilized and cultured follicular oocytes. Jpn J Anim Reprod 34: 191-198 (in Japanese).

Kajihara Y, Kometani N, Koyama K, Kobayashi S, Koshiba $\mathrm{Y}$, Hishiyama K (1989) Bovine in vitro fertilization and embryo transfer.Jpn J Anim Artifi Insemi 134: 8-16 (in Japanese).

Kajihara Y, Kometani N, Kobayashi S, Shitanaka Y, Koshiba Y, Hishiyama K, Shiraiwa K, Goto K (1990) Pregnancy rates and births after co-culture of cumulus cells with bovine embryos derived from in vitro fertilization of in-vitro matured follicular oocytes. Theriogenology 33: 264 (abstr).

Kometani N, Kajihara Y, Kobayashi S, Shitanaka Y, Saitou S, Koshiba Y, Hishiyama K, Shiraiwa K (1989) Cryopresrvation of bovine embryos fertilized in vitro in the medium with glycerol and sucrose. Jpn Soc Zootech Sci 115 (in Japanese, abstr).

Lambert RD, Sirard MA, bernard C, Beland R, Rioux JE, Leclert P, Menard DP, Bedoya M (1986) In vitro fertilization of bovine oocytes matured in vitro and collected at laparoscopy. Theriogenology 25: 117-133.

Leibfried-Rutledge ML, Critser ES, Parrish JJ, First NL (1989) In vitro maturation and fertilization of bovine oocytes. Theriogenology 31: 61-74.
Lu KH, Gordon I, Chen HB, Gallagher M, McGovern H (1988) Births of twins after transfer of cattle embryos produced by in vitro techniques. Vet Res 122: 539-540.

Minato Y (1988) An application of in vitro fertilization to beef cattle production from dairy cow. East Jpn J Anim ET Tech 5: 11-14 (in Japanese).

Miura H, Ito K, Suzuki T, Ishii R (1989) Reproductive activity of bull produced from in vitro fertilization. Animal Husbandry 43: 48-50 (in Japanese).

Niwa K, Ohgoda O (1988) Synergistic effect of caffeine and heaprin on in-vitro fertilization of cattle oocytes matured in culture. Theriogenology 30: 733-741.

Parrish JJ, Parrish JL, Leibfried-Rutledge ML, Crister ES, Eyestone WH, First NL (1986) Bovine in vitro fertilization with frozen-thawed semen. Theriogenology 25: 591-600.

Sirard MA, Lambert RD (1986) Birth of calves after in vitro fertilization using laparoscopy and rabbit oviduct incubation of zygotes. Vet Rec 119: 167-169.

Sugie S (1973) Study of bovine embryo transfer. Jpn Natl Agric Ins Tec Series 62, Tokyo pp 1-72 (in Japanese).

Suzuki T, Ishida T, Sakai Y, Shimohira I (1989) Induction of twinning in dairy heifers by ipsilateral or bilateral transfer of two frozen embryos. Theriogenology 31: 261 (abstr).

Tokumaru M, Goto K, Kajihara Y, Koba M, Nakanishi Y, Ogawa K, Inohae S, Tasaki M, Oota H, Tateyama S, Kawabata $T$ (1989) Methodological investigation on chromosomal preparation of bovine embryoscomparison of in vivo developed blastocysts and those obtained in culture after in vitro fertilization. Jpn J Zootech Sci 60: 761-770 (in Japanese).

Von Bregulla K, Gerlash U, Hahn R (1974) Experiments on the extra-corporal maturation, fertilization and cultivation with bovine sperm cells. Dtsch Tieraerztl Wochenschr 81: 465-476.

Yamashima H (1990) A practical studies for bovine embryo transfer. Jpn J Anim Reprod 35: 20-24 (in Japanese). 
体外成熟，体外受精後，卵丘細胞又は卵丘細胞と子宮内膜上皮細胞を用いた体外培養系により作出 した胚盤胞期胚について，移植所要時間，移植に用いた受肧牛の性周期日齢が受胎率におよぼす影響， および胚日齢と受肧牛の性周期日齢の日齢差の許容範囲について検討を行った．移植は授精後 $7 \sim 9$ 日目に得られた新鮮胚盤胞期胚を用い，胎児日齢55日前後に直腸検查と超音波診断により受胎の有無 を確認した．主なる結果は次のとおりであった。

1。卵丘細胞を用いる体外培養系に子宮内膜上皮細胞をさらに組み合わせて添加する場合は，体外受 精後 2 日目に添加するのが有効であった.

2. 移植に要した時間につては，14分以内と15～50分を比べても受胎率に影響は見られなかった.

3. 移植に用いた胚日齢は受胎率に影響し，受精後7.5日目に得られた肧が， 7.0 日目，あるいは 9.0 日目に得られた胚よりも受胎率が有意に高かった。

4. 移植時の受胚牛の性周期日齢は受胎率に影響し，性周期日齢が 6.0 日齢であった場合は，5.5ある いは8.0 8.5日齢であった場合よりも受胎率が有意に高く，同様に 6.5 日齢の方が5.5日齢の場令より も有意に受胎率が高かった.

5. 移植胚の日齢と性周期日齢の日齢差は受胎率に影響し, 日齢差がー 2.0 日ずれているカが -3.0 日 ずれている場合に対して有意に受胎率が高かった。

6 . 体外成熟, 体外受精, 体外培養胚の移植によって29頭の単子, 10 組の双子, 2 組の三子を得た. また生産された子牛の性別は雌21頭，雄34頭の割合であった。 